\title{
Fatty Acid Composition of Sexes and Body Parts in a Solitary Wasp, Sphex flavipennis (Insecta: Hymenoptera)
}

\author{
Yaşar GÜLMEZ1, Mahfuz ELMASTAŞ²
}

\begin{abstract}
Fatty acid composition in head, thorax, and abdomen of male and female specimens of the solitary wasp species Sphex flavipennis was investigated. Samples were collected from their natural habitats in Tokat province (Turkey). It is determined that, unsaturated fatty acids are high in females whereas saturated fatty acids are high in males. Total unsaturated fatty acids of body parts and sexes were found as: $80.19 \%$ in female head, $75.73 \%$ in male head; $81.57 \%$ in female thorax, $81.43 \%$ in male thorax; $79.03 \%$ in female abdomen, $74.68 \%$ in male abdomen. Total saturated fatty acids of body parts and sexes were found as: $19.57 \%$ in female head but 24.67 $\%$ in male head; $14.83 \%$ in female thorax, $16.91 \%$ in male thorax; $19.77 \%$ in female abdomen, $22.78 \%$ in male abdomen. The highest amounts of fatty acids are oleic acid and linoleic acid ranging between $27.68 \%-52.65 \%$ and $19.00 \%-37.36 \%$, respectively. Differences between body parts as well as male and female insects are due to diverse physiological and metabolic functions.
\end{abstract}

Keywords: Fatty acids, Hymenoptera, Sphex flavipennis

\section{Soliter Yaban Arısı, Sphex flavipennis (Insecta: Hymenoptera)'in Eşey ve Vücut Kısımlarında Yă̆ Asit Kompozisyonu}

ÖZET: Soliter yaban arısı Sphex flavipennis türüne ait erkek ve dişi örneklerin baş, toraks ve abdomen kısımlarında yağ asidi kompozisyonu araştırıldı. Örnekler Tokat ilinde doğal habitatlarından toplandı. Çalışmamızda doymamış yağ asitleri dişilerde, doymuş yağ asitleri ise erkeklerde yüksek bulunmuştur. Eşeyler ve vücut kısımlarına göre toplam doymamış yağ asitleri şu şekilde bulunmuştur: dişinin başında \% 80.19, erkeğin başında \% 75.73; dişinin toraksında \% 81.57, erkeğin toraksında \% 81.43; dişinin abdomeninde \%79.03, erkeğin abdomeninde $\% 74.68$. Toplam doymuş yağ asitleri şu şekilde bulunmuştur: dişinin başında \% 19.57, erkeğin başında \% 24.67; dişinin toraksında \% 14.83, erkeğin toraksında \% 16.91 in; dişinin abdomeninde \% 19.77, erkeğin abdomeninde $\% 22.78$. Yağ asitleri arasında en yüksekleri oleik asit ve linoleik asittir, miktarları sırasıyla 27.68\% - 52.65\% ve 19.00\% $37.36 \%$ arasında değişmektedir. Vücut kısımları ile erkek-dişi arasındaki farklılıklar çeşitli fizyolojik ve metabolik fonksiyonlardan kaynaklanmaktadır.

Anahtar kelimeler: Hymenoptera, Sphex flavipennis, yă̆ asitleri

Gaziosmanpaşa Üniversitesi, Fen-Edebiyat Fakültesi, Biyoloji, Tokat, Türkiye

Gaziosmanpaşa Üniversitesi, Fen-Edebiyat Fakültesi, Kimya, Tokat, Türkiye

Sorumlu yazar/Corresponding Author: Yaşar GÜLMEZ, yasar.gulmez@gop.edu.tr 


\section{INTRODUCTION}

Fatty acids perform many vital functions in insects such as reproduction, embryogenesis, metamorphosis, and flight (Canavoso et al., 2003). They also play regulatory role as being pheromones and hormones (Gilbert and Chino, 1974; Sushchik et al., 2013). They are crucial mediators of insect immunity and are responsible for membrane signaling (Uscian and Stanley-Samuelson, 1994; Tunaz et al., 2003; Stanley et al., 2012). Moreover they are the primary energy source during periods of nonfeeding, such as diapause and long migratory flights, and during nonfeeding stages of development (Beenakkers et al., 1985; Downer, 1985). Fatty acids serve as precursors in the biosynthesis of pheromones, waxes and eicosanoids and as structural components of membranes and defensive secretions, and they are essential components in the function of the cuticle (Blomquist and Dillwith, 1985; StanleySamuelson et al., 1988).

Sphex flavipennis is a solitary wasp species belonging to the Sphecidae family (Insecta: Hymenoptera) known as "thread-waisted wasp". Its members live in temperate regions all over the world and mostly dig nests in sandy areas. Adult wasps feed on nectar of various flowers, but their larvae feed on insects, such as grasshoppers, paralyzed by adult female wasp (Bohart and Menke, 1976). They are very active during daytime; especially females dig nests, catch and paralyze preys, and carry them to the nest etc. Being active predators they control and limit insect populations in the ecosystems while provisioning for their larvae.

Insect flight muscle, the most active tissue known, increases its oxygen consumption to 50-100 folds during flight (Beenakkers et al., 1984). This huge amount of energy is obtained from trehalose, proline, and ketone bodies which are produced from beta oxidation of fatty acids (Gilbert and Chino, 1974; Canavoso et al., 2001; Dooremalen and Ellers, 2010; Arrese and Soulages, 2010). Consequently, lipids play an important role in insect life in many aspects.

Many insect species belonging to different orders have been investigated in terms of fatty acid contents so far (Barlow, 1964; Fast, 1964; Thompson, 1973; Thompson and Barlow, 1974; Nurullahoğlu et al.,
2004; Stewart-Jones et al., 2009; Yocum et al., 2011; Sushchik et al., 2013; Gołebiowski et al., 2013). In some of these studies it was stated that fatty acid composition in insects may differ between sexes and even different developmental stages of the same species (Sushchik et al., 2013; Gołebiowski et al., 2013). However, there is still limited number of investigations about fatty acid contents of different body parts of insects. Most of the studies on fatty acids have been carried out on several species that were reared in laboratory conditions (Fast, 1964; Thompson and Barlow, 1974; Canavoso et al., 2001; Murata and Tojo, 2002; Nurullahoğlu et al., 2004) and the situation in insects that feed naturally in their habitats is a matter of curiosity. The purpose of this study was to determine fatty acid composition of solitary wasp samples, belonging to Sphex flavipennis, collected from the field and compare it between sexes and body parts.

\section{MATERIALS AND METHODS}

\section{Specimens Collection and Identification}

Adult insects were collected using insect net from their natural habitats around Tokat province between 2009-2011. Specimens were identified by one of the authors (Gülmez) and confirmed by comparing with the entomological museum materials found in the Entomological Research Laboratory in Gaziosmanpaşa University, Tokat.

\section{Extraction Procedure}

Male and female specimens were separated and their bodies splitted into three parts (head, thorax, and abdomen) each of which then placed in distinct tubes. Before analysis, each body part was disintegrated under liquid nitrogen. After removing nitrogen, crude oil was obtained from disintegrating parts with light petroleum ether (b.p. $40-60^{\circ} \mathrm{C}$ ) in a Soxhlet. The solvent was removed using rotary evaporator. The extracted oil was used for fatty acid analysis. The oils were saponified by the usual procedure according to the Standard IUPAC methods (IUPAC, 1988). Fatty acids were estherified using official methods (AOAC, 1990).

\section{Gas Chromatographic Analyses}

Gas chromatographic (GC) analyses were performed using a Perkin Elmer Clarus 500 Series 
GC system, in split mode, 50:1, equipped with a flame ionization detector (FID) equipped TR-FAME apolar

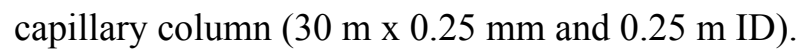

Helium $\left(0.5 \mathrm{~mL} \mathrm{~min}^{-1}\right)$ was used as carrier gas. The injector temperature was set at $250^{\circ} \mathrm{C}$ and the FID was operated at $260^{\circ} \mathrm{C}$. An initial column oven temperature of $100{ }^{\circ} \mathrm{C}$ was elevated to $220^{\circ} \mathrm{C}$ at a rate of $2{ }^{\circ} \mathrm{C} \mathrm{min}^{-1}$ and held for $0 \mathrm{~min}$.

Identification of fatty acid components was accomplished based on comparison of their retention times with those of authentic standards (Supelco 37 Comp. Fatty acid Mix, 18919).

The relative peak area percentages of compounds were calculated based on the FID data.

\section{Statistical Analysis}

The means of three groups were compared through Duncan's Multiple-Range Test after all data were subjected to analysis of variance (Anova). Two group means were compared Paired-Samples $\mathrm{T}$ Test using SPSS statistical software programme (Norusis, 2002).

\section{RESULTS AND DISCUSSION}

In the present study, fatty acid composition of head, thorax, and abdomen of female and male Sphex flavipennis species were determined. Most of the fatty acids were significantly differed between sexes and body parts (Table 1). Our results are generally consistent with the findings of the previous studies on other Hymenoptera (Barlow, 1964; Thompson, 1973; Thompson and Barlow, 1974). The results concerning to unsaturated and saturated fatty acids are discussed separately below.

\section{Unsaturated Fatty Acids}

Total unsaturated fatty acids range from $74.68 \%$ to $81.57 \%$ (Figure 1) and their distribution in body parts of sexes were as follows: head: $80.19 \%$ in female, $75.73 \%$ in male; thorax: $81.57 \%$ in female, $81.43 \%$ in male; abdomen: $79.03 \%$ in female, $74.68 \%$ in male. The values between head and abdomen of sexes differ statistically significant $(\mathrm{p}<0.01)$ (Figure 1). Unsaturated fatty acids are used for diverse physiological functions, such as ovarian development and egg production in female insects (Murata and Tojo, 2002), therefore fatty acid levels may differ between sexes.

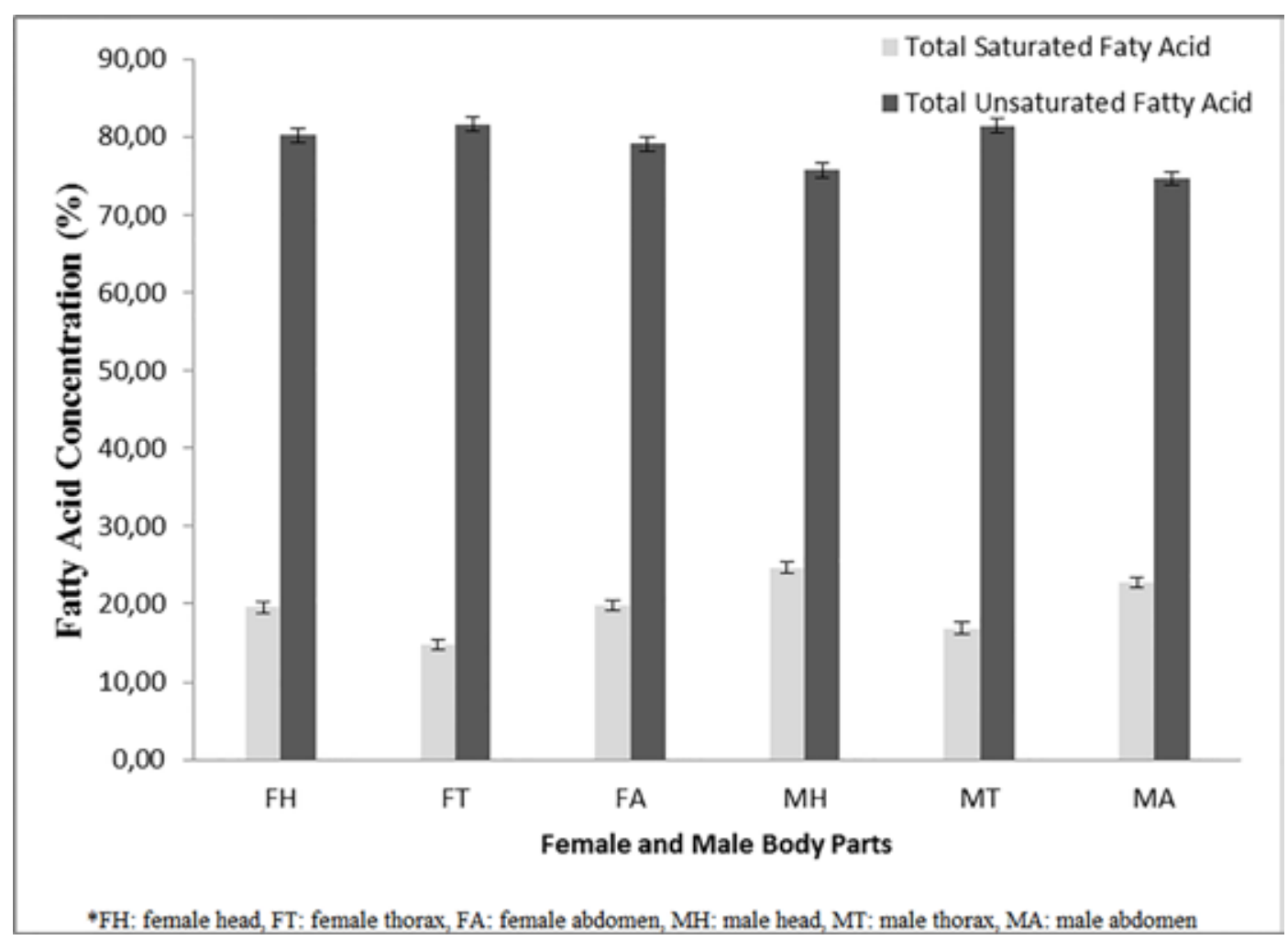

Figure 1. Total saturated fatty acid and total unsaturated fatty acid composition of body parts and sexes 
Oleic acid is the highest of the unsaturated fatty acids, which was found as $31.88 \%$ in female head, $27.68 \%$ in male head; $36.91 \%$ in female thorax 33.42 $\%$ in male thorax; $52.65 \%$ in female abdomen and $47.43 \%$ in male abdomen (Table 1). All the differences between body parts and sexes are statistically significant $(\mathrm{p}<0.01)$. Thompson and Barlow (1974) reported oleic acid ranging between $10 \%$ and $54 \%$ in 30 hymenopteran species and their hosts. Barlow (1964) has found oleic acid in two hymenopteran species (Neodiprion sertifer (Geoffroy) Acanthomyops claviger (Roger)) $33 \%$ and $54 \%$ respectively. Changing of oleic acid between body parts is thought to be resulted either from the food material, i.e., nectar of flowers, or unique functions of the body parts.

Table 1. Fatty acid composition of body parts and sexes of Sphex flavipennis

\begin{tabular}{|c|c|c|c|c|c|c|c|c|c|}
\hline & & Female & & & Male & & & & \\
\hline & & Head & Thorax & Abdomen & Head & Thorax & Abdomen & SEM & P-value \\
\hline C10:0 & Capric Acid & $0.09 \mathrm{~b}$ & $0.00 \mathrm{e}$ & $0.04 \mathrm{~d}$ & $0.11 \mathrm{a}$ & $0.06 \mathrm{c}$ & $0.06 \mathrm{c}$ & 0.01 & 0.01 \\
\hline C12:0 & Lauric Acid & $0.56 \mathrm{bc}$ & $0.67 \mathrm{~b}$ & $0.42 \mathrm{de}$ & $0.43 \mathrm{cde}$ & $1.36 \mathrm{a}$ & $0.41 \mathrm{de}$ & 0.06 & 0.01 \\
\hline C14:0 & Myristic Acid & $0.52 \mathrm{ef}$ & $0.55 \mathrm{ef}$ & $1.18 \mathrm{~b}$ & $0.61 \mathrm{e}$ & $0.47 f$ & $0.75 \mathrm{~d}$ & 0.06 & 0.01 \\
\hline C15:0 & $\begin{array}{l}\text { Pentadecylic } \\
\text { Acid }\end{array}$ & $0.31 \mathrm{c}$ & $0.31 \mathrm{c}$ & $0.18 \mathrm{~d}$ & $0.38 b c$ & $0.44 \mathrm{a}$ & $0.44 \mathrm{a}$ & 0.03 & 0.01 \\
\hline C16:0 & Palmitic Acid & $9.72 \mathrm{e}$ & $8.29 \mathrm{f}$ & $11.98 \mathrm{~d}$ & $12.77 \mathrm{c}$ & $8.76 f$ & $13.52 \mathrm{c}$ & 0.89 & 0.01 \\
\hline C16:1 & Palmitoleic Acid & $1.23 b c$ & $0.75 \mathrm{~d}$ & $1.15 \mathrm{c}$ & $1.34 \mathrm{~b}$ & $0.56 \mathrm{e}$ & $1.14 \mathrm{c}$ & 0.08 & 0.01 \\
\hline C17:0 & $\begin{array}{l}\text { Heptadecylic } \\
\text { Acid }\end{array}$ & $0.17 \mathrm{e}$ & $0.19 \mathrm{~d}$ & $0.11 \mathrm{f}$ & $0.29 b$ & $0.33 \mathrm{a}$ & $0.17 \mathrm{e}$ & 0.01 & 0.01 \\
\hline C17:1 & & $0.08 \mathrm{e}$ & $0.02 \mathrm{~g}$ & $0.12 \mathrm{~d}$ & $0.08 \mathrm{e}$ & $0.22 \mathrm{c}$ & $0.08 \mathrm{e}$ & 0.03 & 0.01 \\
\hline C18:0 & Stearic Acid & $8.07 b$ & $4.20 \mathrm{e}$ & $5.70 \mathrm{~d}$ & $9.94 \mathrm{a}$ & $5.36 \mathrm{~d}$ & $7.27 \mathrm{c}$ & 0.36 & 0.01 \\
\hline C18:1n9c & Oleic Acid & $31.88 \mathrm{~h}$ & $36.91 \mathrm{f}$ & $52.65 b$ & $27.68 \mathrm{i}$ & $33.42 \mathrm{~g}$ & $47.43 c$ & 1.75 & 0.01 \\
\hline C18:2n6c & Linoleic Acid & $36.24 b$ & $34.41 \mathrm{c}$ & $19.00 \mathrm{f}$ & $37.36 \mathrm{a}$ & $33.40 \mathrm{~d}$ & $21.29 \mathrm{e}$ & 2.02 & 0.01 \\
\hline C18:3n3 & Linolenic Acid & $5.84 d$ & $3.61 \mathrm{e}$ & $3.13 \mathrm{fg}$ & $3.42 \mathrm{ef}$ & $10.17 \mathrm{a}$ & $2.82 \mathrm{~g}$ & 0.52 & 0.01 \\
\hline C20:0 & Arachidic Acid & $0.00 \mathrm{c}$ & $0.47 \mathrm{a}$ & $0.12 b$ & $0.00 \mathrm{c}$ & $0.00 \mathrm{c}$ & $0.00 \mathrm{c}$ & 0.03 & 0.01 \\
\hline C20:3n6 & $\begin{array}{l}\text { Arachidonic } \\
\text { Acid }\end{array}$ & $0.00 \mathrm{~g}$ & $3.97 \mathrm{a}$ & $0.48 \mathrm{f}$ & $1.01 \mathrm{~d}$ & $1.53 \mathrm{c}$ & $0.68 \mathrm{e}$ & 0.25 & 0.01 \\
\hline C22:1n9 & Erucic Acid & $3.83 b$ & $1.28 \mathrm{~d}$ & $1.72 \mathrm{c}$ & $4.52 \mathrm{e}$ & $1.45 \mathrm{~d}$ & $0.00 \mathrm{f}$ & 0.29 & 0.01 \\
\hline C24:0 & Lignoceric Acid & $0.13 \mathrm{~d}$ & $0.14 \mathrm{~cd}$ & $0.05 \mathrm{e}$ & $0.14 \mathrm{~cd}$ & $0.14 \mathrm{~cd}$ & $0.18 b$ & 0.04 & 0.01 \\
\hline C24:1 & Nervonic Acid & $1.09 \mathrm{~b}$ & $0.62 d$ & $0.90 \mathrm{c}$ & $0.32 \mathrm{e}$ & $0.70 \mathrm{~d}$ & $1.24 \mathrm{a}$ & 0.08 & 0.01 \\
\hline$\sum$ Saturate & tty Aid & $19.57 f$ & $14.83 \mathrm{~h}$ & $19.77 \mathrm{f}$ & $24.67 \mathrm{c}$ & $16.91 \mathrm{~g}$ & $22.78 \mathrm{e}$ & 0.90 & 0.01 \\
\hline$\sum$ Unsatur & Fatty Acid & $80.19 b$ & $81.57 \mathrm{a}$ & $79.03 \mathrm{c}$ & $75.73 d$ & $81.43 \mathrm{a}$ & $74.68 \mathrm{ef}$ & 0.76 & 0.01 \\
\hline UFA/SFA & & $4.10 \mathrm{c}$ & $5.50 \mathrm{a}$ & $4.00 \mathrm{c}$ & $3.07 \mathrm{e}$ & $4.82 b$ & $3.28 \mathrm{~d}$ & 0.84 & 0.01 \\
\hline
\end{tabular}

Linoleic acid was found as: $36.24 \%$ in female head, 37.36 in male head; $34.41 \%$ in female thorax, 33.40 in male thorax; $19.00 \%$ in female abdomen, $21.99 \%$ in male abdomen. It is statistically significant ( $p<0.01$ ) between all body parts of male and female. Thompson (1973) has found linoleic acid in a wide range, between $3 \%$ and $43 \%$, in other Hymenoptera species. Barlow (1964) has found linoleic acid in two hymenopteran species (Neodiprion sertifer (Geoffroy)
Acanthomyops claviger (Roger)) $45 \%$ and $1 \%$ respectively. Thompson and Barlow (1974) reported linoleic acid ranging between $7 \%$ and $49 \%$ in parasitic hymenopteran species and their hosts.

Linolenic acid was $5.84 \%$ in female head, 3.42 in male head; $3.61 \%$ in female thorax, $10.17 \%$ in male thorax. These differences between head and thorax of male and female individuals are statistically significant 
( $<<0.01$ ). It was found as $3.13 \%$ in female abdomen, $2.82 \%$ in male abdomen, which is not statistically significant $(p>0.05)$. Although this fatty acid is higher in female head and abdomen than in male, it was found in male thorax almost three times higher than that of female.

Palmitoleik acid was $1.23 \%$ in female head, 1.34 $\%$ in male head similarly it was $1.15 \%$ in female abdomen, $1.14 \%$ in male abdomen. Both of the values are not statistically significant ( $p>0.05$ ). It was found to be $0.75 \%$ in female thorax, $0.56 \%$ in male thorax, which is statistically significant $(\mathrm{p}<0.01)$.

Arachidonic acid was not detected in female head, but was $1.01 \%$ in male head; $3.97 \%$ in female thorax, $1.53 \%$ in male thorax; $0.48 \%$ in female abdomen, $0.68 \%$ in male abdomen. All of these differences are statistically significant $(\mathrm{p}<0.01)$.

Erucic acid was $3.83 \%$ in female head, $4.52 \%$ in male head; $1.28 \%$ in female thorax, $1.45 \%$ in male thorax; $1.72 \%$ in female abdomen, not detected in male abdomen. Differences between head and abdomen of female and male are statistically significant $(p<0.01)$, however the difference between thorax of male and female is not $(p>0.05)$.

Nervonic acid has been determined as $1.09 \%$ in female head, $0.32 \%$ in male head; $0.62 \%$ in female thorax, $0.70 \%$ in male thorax; $0.90 \%$ in female abdomen, $1.24 \%$ in male abdomen. Differences between head and abdomen of female and male are statistically significant $(\mathrm{p}<0.01)$, however the difference between thorax of male and female is not ( $p>0.05)$.

\section{Saturated Fatty Acids}

Total saturated fatty acids range from $14.83 \%$ to $24.67 \%$ in the study (Table 1). They were found in body parts as follows: $19.57 \%$ in female head, 24.67 $\%$ in male head; $14.83 \%$ in female thorax, $16.91 \%$ in male thorax; $19.77 \%$ in female abdomen, 22.78 $\%$ in male abdomen (Table 1). All of the values between male and female body parts differ statistically significantly $(p<0.01)$ (Figure 1$)$. In general, saturated fatty acids in all body parts of males were higher than that of females. Since female wasps are more active than males, probably female wasps used saturated fatty acids for energy consumption more than males.
Palmitic acid has been found as $9.72 \%$ in female head, $12.77 \%$ in male head; $8.29 \%$ in female thorax, $8.76 \%$ in male thorax; $11.98 \%$ in female abdomen, $13.52 \%$ in male abdomen. The differences between head and thorax of male and female insects are statisticially significant $(p<0.01)$.

Stearic acid has been found $8.07 \%$ in female head, $9.94 \%$ in male head; $4.20 \%$ in female thorax, $5.36 \%$ in male thorax; $5.7 \%$ in female abdomen, $7.27 \%$ in male abdomen. All the values between male and female body parts differ statistically significant $(\mathrm{p}<0.01)$ (Table 1$)$.

Lauric acid, Miristic acid, Penthadecilic acid, Heptadecilic acid, Lignoseric acid, and Arachidic acid are not discussed here since they were found only in trace amounts (less than $1 \%$ ) (Table 1).

\section{CONCLUSIONS}

In this study, unsaturated fatty acids are found higher than saturated fatty acids in both female and male insects. Essential fatty acids, linoleic acid and linolenic acid, are high in the head and thorax, but low in the abdomen in both sexes. Since essential fatty acids cannot be synthesized de novo, it is thought that these fatty acids are taken from food plants via feeding. Essential fatty acids are metabolized for diverse biological functions to some extent in the abdomen, which helps explain their lower levels.

Non-essential fatty acids, either saturated or unsaturated, could be synthesized de novo when they are required. Therefore many fatty acids are regulated by living organisms according to their needs. For example, defensive alkaloids are stated to be derived from fatty acids, especially from oleic acid (Attygalle et al., 1994). The reason that oleic acid level is high in the abdomen is its necessity in that body part.

Future studies may be carried out to determine if fatty acid composition could be a useful tool to distinguish between insect taxa, especially morphologically identical ones.

\section{ACKNOWLEDGMENTS}

This study is partially supported by Gaziosmanpaşa University BAP, Project Number: 2010/22. 


\section{REFERENCES}

Arrese EL, Soulages JL, 2010. Insect Fat Body: Energy, Metabolism, and Regulation. Annu. Rev. Entomol., 55: 207-225.

Attygalle AB, Blankespoor CL, Eisner T, Meinwald J, 1994. Biosynthesis of a defensive insect alkaloid: Epilachnene from oleic acid and serine. Proc. Natl. Acad. Sci., 91: 12790-12793.

AOAC 1990. Official Methods of Analysis. 15th AOAC International, Washington, DC.

Barlow JS, 1964. Fatty Acids In Some Insect And Spider Fats. Canadian journal of Biochemistry, 42 (10): 1365-1374.

Beenakkers AMT, Van Der Horst DJ, Van Marrewijk WJA, 1984. Insect Flight Muscle Metabolism. Insect Biochem., 14 (3): 243-260.

Beenakkers, A.M.T., Van der Horst, D.J., Van Marrewijk, J.A., Insect lipids and lipoproteins and their role in physiological processes. Prog Lipid Res 1985, 24(1): 19-67.

Blomquist, G.J., Dillwith, J.W. 1985, Cuticular lipids, pp. 117154. In: G.A. Kerkut and L.I. Gilbert (eds.), Comprehensive insect physiology, biochemistry and pharmacology, vol. 10 . Pergamon Press, Oxford, England.

Bohart RM, Menke AS, 1976. Sphecid Wasps of the World. A generic revision. University of California Press, Berkeley, Los Angeles, London. IX+695 p.

Canavoso LE, Jouni ZE, Karnas KJ, Pennington JE, Wells MA, 2001. Fat Metabolism In Insects. Annu. Rev. Nutr., 21: 23-46.

Canavoso LE, Stariolo R, Rubiolo ER, 2003. Flight Metabolism in Panstrongylus megistus (Hemiptera: Reduviidae): the Role of Carbohydrates and Lipids. Mem Inst Oswaldo Cruz, Rio de Janeiro, 98 (7): 909-914.

Dooremalen C, Ellers J, 2010. A moderate change in temperature induces changes in fatty acid composition of storage and membrane lipids in a soil arthropod. Journal of Insect Physiology, 56: 178-184.

Downer, R.G.H., 1985, Lipid metabolism, pp. 77-113. In G.A. Kerkut and L. I. Gilbert (eds.), Comprehensive insect physiology, biochemistry and pharmacology, vol. 10. Pergamon, Oxford, England.

Fast PG, 1964. Insect Lipids: A Review. - Memoirs of the Entomological Society of Canada, 96: 5-50.

Gilbert LI, Chino H, 1974. Transport of lipids in insects. J. Lipid Res., 15: 439-456.

Gołebiowski M, Urbanek A, Oleszczaka A, Dawgul M, Kamysz W, Bogus MI, Stepnowski P, 2013. The antifungal activity of fatty acids of all stages of Sarcophaga carnaria L. (Diptera: Sarcophagidae). Microbiol Res., 169 (4): 279-286.

IUPAC, 1988. International Union of Pure and Applied Chemistry, Standard Methods and Applications. Marcel Dekker, New York.
Murata M, Tojo S, 2002. Utilization of lipid for flight and reproduction in Spodoptera litura (Lepidoptera: Noctuidae) Eur. J. Entomol., 99: 221-224.

Norusis MJ, 2002. SPSS Base 11.5 User's Guide, (Chicago, IL, SPSS Inc.).

Nurullahoğlu ZÜ, Uçkan F, Sak O, Ergin E, 2004. Total lipid and fatty acid composition of Apanteles galleria and its parasitized host. Annals of the Entomological Society of America, 97: 1000-1006.

Stanley D, Haas E, Miller J, 2012. Eicosanoids: Exploiting Insect Immunity to Improve Biological Control Programs. Insects, 3: $492-510$.

Stanley-Samuelson, D.W., 1988, Jurenka, R.A., Crips, C., Blomquist, G.J., de Renobales, M., 1988, Fatty acids in insects: composition, metabolism and biological significance. Arch Insect Biochem Physiol 9(1): 1-33.

Stewart-Jones A, Stirrup TJ, Hodges RJ, Farman DI, Hall DR, 2009. Analysis of free fatty acids in food substrates and in the dust and frass of stored-product pests: Potential for species discrimination? Journal of Stored Products Research, 45: $119-124$

Sushchik NN, Yurchenko YA, Gladyshev MI, Belevich OE, Kalachova GS, Kolmakova AA, 2013. Comparison of fatty acid contents and composition in major lipid classes of larvae and adults of mosquitoes (Diptera: Culicidae) from a steppe region. Insect Science, 20: 585-600.

Thompson SN, 1973. A Review And Comparative Characterization of the Fatty Acid Compositions of Seven Insect Orders. Comp. Biochem. Physiol., Vol. 45B: 467-482.

Thompson SN, Barlow JS, 1974. The Fatty Acid Composition of Parasitic Hymenoptera and its Possible Biological Significance. Annals of the Entomological Society of America, 67(4): 627-632.

Tunaz H, Park Y, Büyükgüzel K, Bedick JC, Aliza ARN, Stanley DW, 2003. Eicosanoids in Insect Immunity: Bacterial Infection Stimulates Hemocytic Phospholipase A2 Activity in Tobacco Hornworms. Archives of Insect Biochemistry and Physiology, 52: 1-6.

Uscian JM, Stanley-Samuelson DW, 1994. Fatty acid compositions of phospholipids and triacylglycerols from selected terrestrial arthropods. Comp. Biochem. Physiol., 107B (3): 371-379.

Yocum GD, Buckner JS, Fatland CL, 2011. A comparison of internal and external lipids of nondiapausing and diapause initiation phase adult Colorado potato beetles, Leptinotarsa decemlineata. Comparative Biochemistry and Physiology, Part B 159: 163-170. 